\title{
PROBLEMATYKA TOŻSAMOŚCI METROPOLITALNEJ W ZARZAZDZANIU TERYTORIALNYM METROPOLIĄ KRAKÓW
}

\section{Abstract \\ The Issue of Metropolitan Identity in Managing the Development of Cracow Metropolis}

The article presents the metropolitan identity - understood as a new type of organizational identity, specific to metropolitan centers - and aims to assess its relevance to the territorial management of metropolis. Theoretical considerations were performed using the analysis of documents related to Cracow Metropolitan Area.

Keywords: organizational identity, metropolitan identity, metropolisation, Cracow, territorial management.

\section{Streszczenie}

W artykule zaprezentowano tożsamość metropolitalną, stanowiącą nowy typ tożsamości organizacyjnej, właściwy ośrodkom metropolitalnym, a także dokonano próby oceny jej znaczenia dla skutecznego zarządzania terytorialnego metropolią. Rozważania teoretyczne przeprowadzone zostały z wykorzystaniem analizy dokumentów dotyczących Krakowskiego Obszaru Metropolitalnego.

Słowa kluczowe: tożsamość organizacyjna, tożsamość metropolitalna, metropolizacja, Kraków, zarządzanie terytorialne.

\section{Wstęp}

Procesy metropolizacji silnie wpływają na charakter zarządzania terytorialnego w jednostkach samorządu terytorialnego (JST), co sprawia, że kształtowanie oraz sprawna realizacja polityk publicznych wymagają trwałej współpracy wielu podmiotów. Interaktywne i partnerskie współrządzenie wymaga od przedstawicieli JST oraz innych interesariuszy aktywnego zaangażowania w kształtowanie odpowiedniej kultury i tożsamości organizacyjnej, wspólnej dla metropolii oraz 
jej obszaru funkcjonalnego. W tym kontekście szczególnie istotne staje się wypracowanie jednolitej delimitacji Metropolii Kraków, co pozwoli na, co najmniej wstępne, opracowanie ram współpracy i katalogu podmiotów mogących inspirować polityki publiczne oraz uczestniczyć w procesach sprawnego ich wdrażania.

Celem artykułu jest wskazanie znaczenia tożsamości metropolitalnej dla skutecznego zarządzania terytorialnego metropolią Kraków.

W opracowaniu wykorzystano współczesne koncepcje zarządzania terytorialnego, zarządzania interaktywnego, a także zagadnień związanych z procesem metropolizacji oraz kulturą i tożsamością organizacyjną. Przedstawiono także propozycję elementów składowych tożsamości metropolitalnej.

Rozważania teoretyczne wsparto analizą dokumentów delimitujących Krakowski Obszar Metropolitalny.

\section{Tożsamość metropolitalna w procesie zarządzania rozwojem terytorialnym}

Postępująca globalizacja gospodarki oraz wzrastająca międzynarodowa mobilność ludzi, towarów, usług i kapitału nieustannie wpływają na kształt procesów urbanizacyjnych zachodzących w największych polskich miastach. Wynikające $\mathrm{z}$ tego zjawiska przemiany ekonomiczne, społeczne, kulturowe i przestrzenne dotyczące rozwoju ośrodków miejskich coraz częściej określane są mianem metropolizacji. W literaturze przedmiotu proces ten rozumiany jest w kategoriach funkcjonalnych i definiowany jako wykształcanie się nowego typu struktury przestrzennej, to znaczy miasta zyskującego przewagę nad innymi jednostkami w regionie oraz budującego swoje znaczenie w wymiarze międzynarodowym [Markowski, Marszał, 2006: 10]. Metropolizacja związana jest więc z powstawaniem metropolii, które z kolei wytwarzają „obszary metropolitalne”, wykraczające poza tradycyjne granice administracyjne.

Pod pojęciem metropolii rozumie się duże ośrodki miejskie, cechujące się wysokim poziomem usług oraz infrastruktury, a także innowacyjnością we wszystkich podstawowych dziedzinach ich działalności [Jałowiecki, 2000: 33; Kowalewski, 2005: 15]. Do najważniejszych kryteriów definiujących miasta jako metropolie zaliczyć należy ponadto [Markowski, Marszał, 2006: 13; Jałowiecki, 2005: 5]: wyjątkowość i specyfikę miejsca (jego znaczenie historyczne oraz walory architektoniczno-urbanistyczne) oraz występowanie silnych dośrodkowych powiązań integracyjnych z rozległą zurbanizowaną strefą podmiejską.

Elementem wyróżniającym metropolie spośród innych miast jest spełnianie przez ośrodki tego typu specyficznych funkcji metropolitalnych, to jest funkcji centralnych wysokiego rzędu hierarchicznego o zasięgu co najmniej krajowym [Markowski, Marszał, 2006: 12-13]. Przede wszystkim muszą one posiadać wynikające z zasobów wewnętrznych - egzogeniczne znaczenie ponadregionalne, dotyczące świadczenia usług najwyższego rzędu. Obejmują one w szczególności [Smętkowski, Jałowiecki, Gorzelak 2009: 58-59]: funkcje kontrolne i zarządcze, 
atrakcyjność zewnętrzną, potencjał akademicki oraz kulturalny, a także dostępność transportową. Oznacza to, że metropolie zyskują swoje funkcje metropolitalne w głównej mierze w wyniku spełniania następujących kryteriów [Parysek, 2000]:

- obecność instytucji reprezentujących struktury kierowania i zarządzania międzynarodowych korporacji gospodarczych;

- obecność struktur kierownictwa światowych instytucji finansowych (banki) i głównych regulatorów rynków kapitałowych (giełdy);

- szybkie i częste połączenia komunikacyjne z głównymi ośrodkami życia gospodarczego;

- obecność najwyższego standardu placówek naukowych (uniwersytety, instytuty badawcze) i technologicznych (centra nowych technologii, technopolie, parki technologiczne);

- działanie najwyższej rangi placówek kulturalnych (muzea, galerie, opery, orkiestry symfoniczne, teatry) i odbywanie się imprez oraz festiwali artystycznych,

- wyjątkowość miasta, wynikająca z jego położenia, specyfiki atmosfery, standardu bazy noclegowej i gastronomicznej, instytucji rozrywki.

Należy przy tym pamiętać, że funkcje metropolitalne pełni zarówno miasto (metropolia), jak i - otaczający je - obszar metropolitalny.

Obszar metropolitalny można zdefiniować w konsekwencji jako wielkomiejski układ osadniczy, złożony z wielu jednostek oraz terenów o wysokim stopniu zurbanizowania [Markowski, Marszał, 2006: 15]. Ze względu na fakt, że jego rozwój wynika z powiększania się zasięgu oddziaływania funkcji metropolitalnych, obejmuje on strefę o bezpośrednim zasięgu oddziaływania oraz tereny potencjalnych możliwości rozwojowych. Kształtowanie się obszaru metropolitalnego jest związane z procesami migracji ludności oraz przenoszenia działalności gospodarczej poza ośrodek centralny. Dlatego też należy się zgodzić z Tadeuszem Markowskim, że „obszar metropolitalny jest zbiorem o rozmytych granicach i sztywne wyznaczenie jego granicy administracyjnej czy granic statystycznych dla celów poznawczych nie jest rozwiązaniem wystarczającym" [2007: 328]. Niemniej jednak dotychczas nie zaproponowano ogólnie przyjętej delimitacji obszaru tego typu.

Zarządzanie terytorialne jest definiowane jako kierowanie „podsystemami wyznaczonych obszarów dla osiągnięcia określonych przez zarządzającego celów", a za jego podmiot uznaje się zamieszkującą dane terytorium wspólnotę, ,działającą poprzez władze publiczne i administrację lub innego typu reprezentujące ją instytucje" [Noworól, 2013: 39]. Rozwój jest natomiast rozumiany jako proces długofalowych zmian ilościowych i jakościowych dokonujący się w gospodarce i społeczeństwie (między innymi stopień usieciowienia organizacji oraz poziom zaspokajania potrzeb społecznych) [Markowski, 2008: 13-14].

Specyfika organizacji terytorialnej, jaką jest metropolia (miasto centralne wraz $z$ obszarem funkcjonalnym), sprawia, że efektywna implementacja polityk publicznych wymaga trwałej współpracy wielu jednostek samorządu terytorialnego. Oznacza to, że zarządzanie terytorialne powinno mieć charakter interaktywnego współrządzenia, w którym sukces ,zależy od wyzwolenia przez ośrodek kierowniczy zdolności uczestników systemu społecznego do aktywnego przystosowania 
się i tworzenia nowych rozwiązań poprzez proces społecznego komunikowania, negocjowania i porozumiewania się" [Hausner, 2010: 98]. Istotnymi założeniami tej koncepcji są [Dobrowolski, 2014: 183]: zaangażowanie interesariuszy, jawność, przejrzystość, równość, brak dyskryminacji w korzystaniu z usług publicznych oraz rozliczalność decydentów.

Koncepcja łączenia i współpracy podmiotów zaangażowanych w funkcjonowanie metropolii jest bezpośrednio powiązana z koniecznością kształtowania i nadawania kierunku procesom metropolizacyjnym, zachodzącym wewnątrz tego typu organizacji terytorialnej. Jak słusznie zauważa Michel Bassand [2007], procesy te można sklasyfikować poprzez nadanie im odpowiednich atrybutów, tworzących tak zwany heksagon metropolizacji. Tak określone procesy metropolizacyjne obejmują zarówno tworzenie odpowiedniej infrastruktury sieci i mobilności, kontrolowanie procesu suburbanizacji (rozlewania się metropolii), jak i systematyzację funkcjonalną obszaru (tzn. wydzielanie się stref mieszkaniowych, usługowych, biznesowych itp.), a także rozwijanie infrastruktury metropolitalnej o znaczeniu globalnym.

Sprawne i efektywne zarządzanie terytorialne metropolią - samo w sobie będące jednym $\mathrm{z}$ atrybutów procesów metropolizacji, polegającym na konieczności instytucjonalizacji politycznej obszaru (metropolitarny governance) - wymaga także podejmowania działań na rzecz przeciwdziałania negatywnym efektom przekształcania się aglomeracji w metropolie. Michel Bassand [2007] zalicza do nich przede wszystkim konieczność zintegrowania polityk publicznych mających przeciwdziałać procesom segregacji przestrzennej i postępującemu rozwarstwieniu społecznemu, a także prowadzenia działań integrujących zróżnicowaną społecznie i kulturowo społeczność. Szczególnego znaczenia nabiera właśnie kwestia tożsamości mieszkańców metropolii, gdyż „,w swoich zachowaniach wyrażają [oni] zarówno własną lokalność, jak i tożsamość metropolitalną, a jednocześnie tkwią aktywnościami i wirtualnie w innych częściach świata" [Klasik et al., 2014: 21].

Najważniejsze dla osiągnięcia sprawności funkcjonowania wspólnoty metropolitalnej jest więc zapewnienie partycypacji wszystkich wchodzących $\mathrm{w}$ jej skład JST w procesach formułowania celów i założeń polityk rozwoju, przy jednoczesnym działaniu na rzecz redukowania i łagodzenia sporów oraz możliwie najbardziej efektywnego wykorzystania potencjałów tych podmiotów. Oznacza to, że - wynikające między innymi z postępującej metropolizacji oraz nowego paradygmatu polityki regionalnej ${ }^{1}$ - zmiany zachodzące na obszarze jednostek samorządu terytorialnego wymuszają wprowadzanie zmian $\mathrm{w}$ sposobie funkcjonowania społeczności lokalnych. Przemiany te oznaczają także konieczność

${ }^{1}$ Nowy paradygmat polityki regionalnej rozumiany jest w artykule zgodnie z koncepcją Aleksandra Noworóla (2013) i polega przede wszystkim na: uwzględnieniu konsekwencji nowych wyzwań społeczno-gospodarczych, bazowaniu w większym stopniu na endogenicznym potencjale rozwojowym terytorium, promowaniu podejścia strategicznego i uczeniu się poprzez prospektywną ewaluację, a także uznanie spójności terytorialnej jako celu rozwojowego oraz podkreśleniu roli współdziałania w ramach zarządzania wielopasmowego rozwojem. 
przekształcenia kultury w organizacji terytorialnej, jaką jest metropolia (ośrodek centralny wraz z obszarem funkcjonalnym).

Kultura organizacyjna to ,schemat podstawowych założeń wynalezionych, odkrytych czy wypracowanych przez daną grupę w trakcie uczenia się metod radzenia sobie z problemami przystosowania zewnętrznego i integracji wewnętrznej, które funkcjonowały na tyle dobrze, aby uznać je za prawomocne, a przez to, aby nowi członkowie uczyli się ich jako poprawnych sposobów postrzegania, myślenia i odczuwania w odniesieniu do tych problemów" [Schein, 1985: 6]. Wydaje się, że w obliczu zachodzących w funkcjonowaniu samorządów zmian te ,schematy podstawowych założeń" ulegają przekształceniu, którego skutkiem powinno być dopasowanie się funkcjonowania wspólnoty do nowej rzeczywistości społecznej.

Kultura organizacyjna rozumiana jest więc $\mathrm{w}$ tym ujęciu jako zmienna wewnętrzna, to znaczy element (podsystem) organizacji terytorialnej, którym można efektywnie zarządzać. W jej centrum natomiast znajduje się tożsamość organizacyjna, czyli „symboliczna, zbiorowa interpretacja ludzi tworzących organizację, odnosząca się do tego, czym organizacja jest i jaka chciałaby być" [Sułkowski, 2008: 17]. Trzeba się jednocześnie zgodzić z Stuartem Albertem i Davidem Allredem Whettenem [2004: 90], stwierdzając, że jest to swoisty konsensus dotyczący: wartości, kultury organizacyjnej, filozofii działania, orientacji, misji i wizji oraz członkostwa organizacyjnego, spełniający następujące kryteria [Sułkowski, 2008: 17]:

- kryterium stwierdzania kluczowych cech organizacji - tożsamość organizacji odzwierciedla jej esencję, podstawowe kwestie „egzystencjalne”, wokół których powstał konsens członków organizacji;

- kryterium stwierdzania zróżnicowania - tożsamość organizacyjna tworzona jest przez poczucie odrębności członków organizacji, identyfikują się oni z organizacją, definiując jej granice, kryteria przynależności i wykluczania;

- kryterium ciągłości czasowej - tożsamość jest efektem poczucia kontynuacji temporalnej, a organizacja jest zintegrowana poprzez konwencje prawne i zarządcze, które z kolei są podtrzymywane dzięki przekonaniu członków organizacji i innych w otoczeniu o kontynuacji istnienia samej organizacji, pomimo dokonujących się zmian.

Tożsamość organizacyjna składa się w rezultacie między innymi z wzorców i wartości kulturowych, podstawowych założeń, norm społecznych i organizacyjnych, a także sposobów komunikowania się (mitów, narracji), symboli czy rytuałów.

W obliczu zachodzących za sprawą procesów globalizacji i metropolizacji zmian konieczne jest tym samym kształtowanie tożsamości organizacyjnej umożliwiającej skuteczne i efektywne ekonomicznie zarządzanie terytorialne metropoliami. Ten wyłaniający się nowy typ tożsamości zbiorowej można nazwać tożsamością metropolitalną, której osiągnięcie możliwe będzie tylko w przypadku stymulacji zachodzącej właśnie zmiany kulturowej. Proces asymilacji zmienianej kultury składa się z następujących etapów [Killman, Covin, 2008: 74]:

- wydobycie na powierzchnię aktualnie obowiązujących norm;

- wyznaczenie nowych kierunków rozwoju; 
- ustalenie nowych norm kulturowych;

- identyfikacja luki kulturowej;

- wyeliminowanie luki kulturowej.

Nieefektywność działań na rzecz wyznaczenia nowych kierunków rozwoju może doprowadzić do zakłócenia funkcjonowania metropolii przez negatywne efekty braku zmiany kulturowej [Schein, 2004: 30-44]:

- ograniczanie możliwości wdrażania nowych strategii - wartości dotychczas obowiązujące w kulturach społeczności lokalnych mogą się kłócić z założeniami nowych polityk publicznych i utrudniać współpracę przy kształtowaniu dokumentów planistycznych;

- powodowanie problemów w sytuacji aliansów i połączeń podmiotów nieadekwatność kultur lokalnych utrudniać może partycypowanie wszystkich JST w założeniach nowego paradygmatu zarządzania terytorialnego;

- trudności z wdrażaniem nowych form organizowania, nowych technologii i ze zmianami struktury - przemiany tego typu są niezbędne do prawidłowego funkcjonowania ośrodków metropolitalnych;

- generowanie konfliktów międzygrupowych w organizacjach;

- kłopoty z systemem komunikacji - różne perspektywy kulturowe poszczególnych społeczności lokalnych uniemożliwiają osiągnięcie zbieżności percepcji;

- trudności z socjalizacją wtórną jednostek - prowadzące do ograniczenia możliwości asymilacji nowych członków organizacji;

- obniżenie efektywności współpracy.

Decydujące dla sprawnego zarządzania terytorialnego metropoliami w obliczu nowego paradygmatu polityki rozwoju jest zatem ustalenie norm kulturowych wspólnych dla zbiorowości ludzkiej zamieszkującej obszary metropolitalne. Zadanie to jest o tyle trudne, że tożsamość metropolitalna będzie w znacznym stopniu zależna od norm i wartości podzielanych przez społeczności JST wchodzących w jej skład. Oznacza to, że choć należałoby raczej mówić o tożsamościach metropolitalnych, to można jednak wskazać kilka elementów, które - w dobie globalizacji, metropolizacji oraz nowego paradygmatu zarządzania rozwojem - mogą przekładać się na wartości wspólne, właściwe wszystkim mieszkańcom obszarów metropolitalnych:

- funkcjonowanie sieciowego społeczeństwa obywatelskiego, wykraczającego swoim zasięgiem poza klasycznie pojmowane granice administracyjne, oraz uwzględnienie znaczenia mobilności rzeczywistej i wirtualnej członków danej zbiorowości;

- akceptacja rozwoju sieciowych form organizacji działalności gospodarczej, społecznej i kulturowej;

- przekonanie o konieczności aktywnej partycypacji przedstawicieli społeczności metropolitalnej w kształtowaniu polityk publicznych obszarów metropolitalnych - prowadzące do zwiększenia skuteczności interwencji publicznych i ukierunkowanie ich na rzeczywiste potrzeby społeczne i gospodarcze; 
- wielopoziomowe i interaktywne zarządzanie (współrządzenie) metropolią poprzez związki i stowarzyszenia JST wchodzącee w jej skład, a także poprzez rozmaite partnerstwa międzysektorowe - wspólne negocjowanie, monitorowanie i koordynowanie polityk publicznych z wykorzystaniem endogenicznych potencjałów danego obszaru funkcjonalnego.

Tożsamość metropolitalna nie ma tym samym charakteru emotywnego, właściwego dotychczasowym tożsamościom narodowym i regionalnym. Do jej głównych wartości należą raczej: poszanowanie praw człowieka, kult rzeczywistej i wirtualnej mobilności, zaufanie społeczne oraz szeroka partycypacja podmiotów społecznych w zarządzaniu. Niemniej jednak wykształcenie powiązań pomiędzy społecznościami wchodzących w skład metropolii JST będzie także wymagać wykorzystania tradycyjnych norm i wzorów postępowań w nich obowiązujących.

\section{Kraków jako metropolia. Problemy delimitacji}

Wyznaczone w dokumentach planistycznych delimitacje Krakowskiego Obszaru Metropolitalnego sugerują traktowanie wchodzących w ich skład jednostek samorządu terytorialnego jako spójnego systemu - organizacji terytorialnej. Organizację tego typu definiuje się w literaturze przedmiotu jako wyznaczoną przestrzennie (jednostkę podziału terytorialnego) dla celów wykonywania administracji publicznej, zamieszkaną przez wspólnotę obywateli połączonych siecią (mniej lub bardziej sformalizowanych) powiązań i stosunków [Noworól, 2007: 22]. Do jej najważniejszych potencjałów należy zaliczyć: zasoby naturalne i finansowe oraz kapitał ludzki i społeczny.

Ocena stanu i sytuacji demograficznej Krakowa pozwala stwierdzić, że spełnia on kryteria cechujące współczesne metropolie. Według danych z końca 2014 roku ośrodek miejski liczy 760,7 tys. mieszkańców, a cały obszar metropolitalny 1498499 osób [BDL, GUS2014]. Ponadto Kraków pod względem funkcji metropolitalnych plasuje się na drugim miejscu w rankingu miast polskich [Smętkowski, Jałowiecki, Gorzelak, 2009: 50]. Według Raportu PwC [Raporty, 2011: 11] cechuje go przede wszystkim znakomity wizerunek oraz atrakcyjność turystyczna, wynikające z potencjału kulturalnego i religijnego, a także wysoki poziom kapitału ludzkiego, społecznego i edukacyjnego. Potencjały te są wzmacniane przez sprawnie działający system polityczno-administracyjny oraz relatywnie dobrze rozwiniętą infrastrukturę. Co więcej, w porównaniu do innych polskich ośrodków metropolitalnych, Kraków gwarantuje wysoką jakość życia, pomimo problemów dotyczących stanu środowiska naturalnego.

W wyniku przemian związanych z zaspokajaniem funkcji metropolitalnych Kraków coraz częściej jest uznawany za ,potencjalny ośrodek globalny” [Derruder et al., 2010], zdolny do osiągnięcia statusu metropolii o zasięgu światowym w przypadku utrzymania pozytywnych trendów rozwojowych. Wydaje się, że decydujące będzie w tym procesie działanie na rzecz zwiększenia dynamiki rozwoju gospodarczego - pod tym względem Kraków wyprzedzają Poznań oraz 


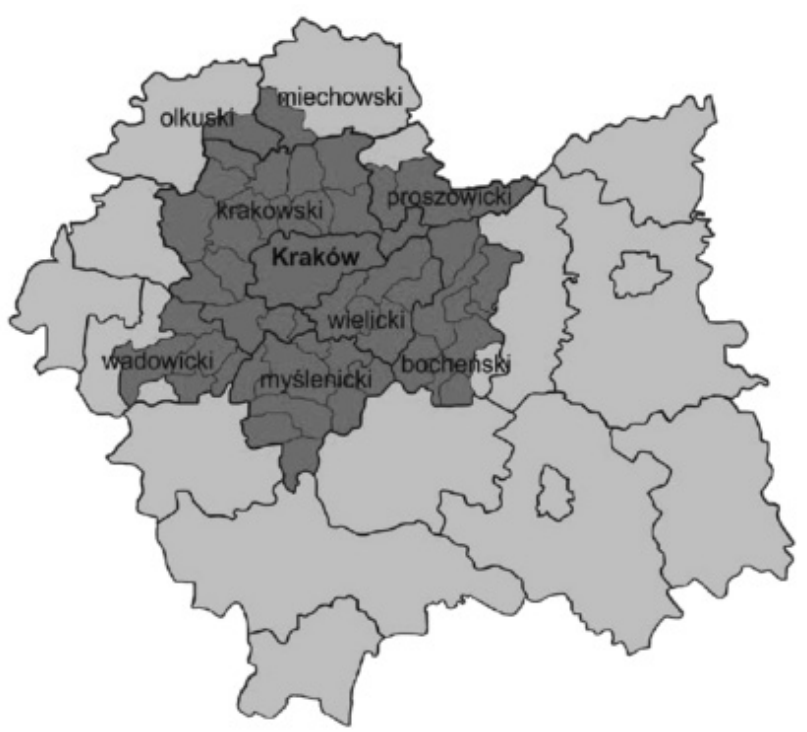

Rysunek 1. Delimitacja Krakowskiego Obszaru Metropolitalnego zawarta w Planie Zagospodarowania Przestrzennego Województwa Małopolskiego

Źródło: Krakowski Obszar Metropolitalny w latach 2004-2011, Urząd Statystyczny w Krakowie, Kraków 2013, s. 25.

Wrocław [Raporty, 2011: 8]. W obu tych ośrodkach wartość PKB per capita jest relatywnie wyższa.

Istotne w tym aspekcie jest także dookreślenie funkcjonalnych granic Krakowskiego Obszaru Metropolitalnego (KOM). Obecnie bowiem nawet w oficjalnych dokumentach planistycznych funkcjonuje kilka delimitacji, które różnią się zasięgiem. Wyraźnie jednak uwidaczniają się dwa główne podejścia do kryteriów wyznaczenia terytorium tego typu [Huculak et al., 2013: 135]: węższe (obejmujące gminy znajdujące się w najbliższym otoczeniu Krakowa) oraz szersze (oparte na funkcjonalnym kryterium dojazdów do pracy). Do oficjalnych dokumentów planistycznych wyznaczających Krakowski Obszar Metropolitalny w szerokim ujęciu należy zaliczyć przede wszystkim Plan Zagospodarowania Przestrzennego Województwa Małopolskiego 2 (PZPWM) oraz przygotowane przez Ministerstwo Rozwoju Regionalnego Kryteria delimitacji Miejskich Obszarów Funkcjonalnych ośrodków wojewódzkich.

W PZPWM za podstawowe jednostki delimitacji KOM uznano gminy, które - ze względu na swoją powierzchnię i liczbę mieszkańców - pozwalają na możliwie najdokładniejsze określenie oddziaływania centralnego ośrodka miejskiego. W takim ujęciu do terytorium Krakowskiego Obszaru Metropolitalnego zaliczono miasto Kraków oraz 50 gmin, w tym 34 wiejskie oraz 15 miejsko-wiejskich

\footnotetext{
${ }^{2}$ Uchwała nr XV/174/03 Sejmiku Województwa Małopolskiego z dnia 22 grudnia 2003 r.
} 
(rysunek 1). Głównymi kryteriami funkcjonalnymi takiego rozstrzygnięcia są: dojazdy do pracy, migracje na pobyt stały, a także dojazdy młodzieży do szkół ponadgimnazjalnych i uczelni, dojazdy do usług rynkowych (handel, obsługa finansowo-bankowa) oraz dojazdy do usług nierynkowych (kultura, sztuka, służba zdrowia, sport) [PZPWM, 2003: 165]. Kryteria funkcjonalne zostały ponadto uzupełnione o dodatkowe zmienne z zakresu społeczeństwa lokalnego, rozwoju gospodarczego i przestrzennego zagospodarowania obszaru.

Badania Piotra Raźniaka [2012: 79-80] wykazały, że w tak wyznaczonym KOM nastąpił w ostatnich latach szybki wzrost społeczno-gospodarczy. Kraków ma coraz większą liczbę powiązań międzynarodowych, coraz więcej firm lokuje swoje przedstawicielstwa w ośrodku centralnym. Jednocześnie nasilają się procesy suburbanizacji wykraczające poza gminy bezpośrednio graniczące z Krakowem, zwłaszcza w jednostkach położonych blisko rozwiniętej infrastruktury autostradowej.

W takich warunkach także obszary peryferyjne Krakowskiego Obszaru Metropolitalnego zaczęły się bardzo szybko bogacić i zmniejszać dystans do najbardziej rozwiniętych gmin, a przemianom ulegają nie tylko gminy miejsko-wiejskie, ale także gminy wiejskie [Huculak et al., 2013: 145-146]. Zmiany te dotyczą nie tylko dotychczasowych funkcji tego typu jednostek terytorialnych, ale także zagospodarowania przestrzennego oraz struktury społecznej, co prowadzi do ewoluowania obyczajów i kultury.

Węższą delimitację Krakowskiego Obszaru Metropolitalnego zaproponowano w przygotowanych przez Ministerstwo Rozwoju Regionalnego Kryteriach delimitacji Miejskich Obszarów Funkcjonalnych ośrodków wojewódzkich z 2013 roku. Dokument ten powstał jako uzupełnienie do Krajowej Strategii Rozwoju Regionalnego oraz Koncepcji Przestrzennego Zagospodarowania Kraju 2030, a jego zadaniem było wyznaczenie obszarów funkcjonalnych odpowiadających nowemu paradygmatowi polityki rozwoju, opartemu na wykorzystaniu potencjałów endogenicznych danego terytorium. Przyjęto w nim następujące zasady delimitacji [Śleszyński, 2013: 182-183]:

- administracyjne - rozróżnienie rdzenia obszaru (miasta-stolicy) oraz stref zewnętrznych;

- topologiczne - zachowanie ciągłości przestrzennej oraz kierowanie się przekonaniem, że każda gmina może przynależeć do wyłącznie jednego obszaru funkcjonalnego;

- spełniania kryteriów - stopień, w jakim gminy spełniały wyznaczone kryteria funkcjonalne (liczba wyjeżdzających do pracy najemnej do miasta-stolicy na 1000 mieszkańców) oraz społeczno-gospodarcze (m.in. udział podmiotów gospodarczych na 1000 mieszkańców, gęstość zaludnienia, czy liczba mieszkań oddanych do użytku na 1000 mieszkańców).

Wyznaczony za pomocą tego podejścia Krakowski Obszar Funkcjonalny składa się z miasta-rdzenia Krakowa oraz 22 gmin (w tym 8 miejsko-wiejskich i 14 wiejskich), co przekłada się na terytorium o łącznej powierzchni $1991 \mathrm{~km}^{2}$ i 1175 tys. zameldowanych mieszkańców (rysunek 2). Dokument dopuszcza możliwość pewnej (nieznacznej) korekty zaproponowanej delimitacji, niemniej jednak zmiany 

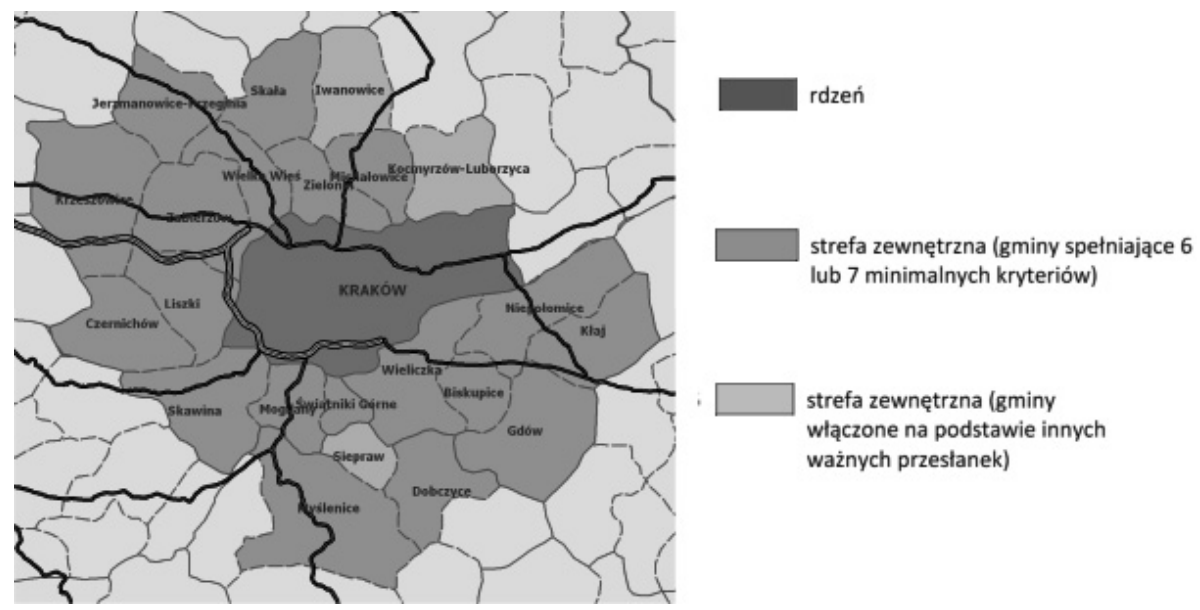

Rysunek 2. Delimitacja Krakowskiego Obszaru Metropolitalnego zawarta w Kryteriach delimitacji Miejskich Obszarów Funkcjonalnych ośrodków wojewódzkich

Źródło: Kryteria delimitacji Miejskich Obszarów Funkcjonalnych ośrodków wojewódzkich, Ministerstwo Rozwoju Regionalnego, Warszawa 2013, s. 16.

te nie mogą naruszać głównego celu delimitacji, czyli „bardziej racjonalnego i efektywnego zarządzania polityką rozwoju na tych obszarach oraz koordynacjii efektywności działań publicznych na ich terenie" [Kryteria delimitacji, 2013: 5].

Zadanie to jest o tyle trudne, że w praktyce funkcjonowania jednostek samorządu terytorialnego - obok dokumentów o charakterze strategicznym - funkcjonują także delimitacje węższe, stosowane na potrzeby wykorzystania środków finansowych z Unii Europejskiej. Do 2013 roku alokacja funduszy europejskich była prowadzona z wykorzystaniem delimitacji KOM zawartej w Małopolskim Regionalnym Programie Operacyjnym na lata 2007-2013 (rysunek 3). Obejmował on swoim zasięgiem Kraków oraz 15 gmin znajdujących się w jego najbliższym otoczeniu (w tym 5 gmin miejsko-wiejskich i 10 gmin wiejskich), a także - leżące poza tym kręgiem - gminy Brzeźnica oraz Kłaj. Według danych za 2013 rok [BDL, GUS] jest to obszar o powierzchni $1588 \mathrm{~km}^{2}$, zamieszkiwany przez 1089129 mieszkańców. Za najistotniejsze dla rozwoju KOM uznano przedsięwzięcia z zakresu: wzmocnienia potencjału badawczego, a także rozwoju funkcji metropolitalnych oraz transportu metropolitalnego.

Zmiana paradygmatu polityki rozwoju regionalnego doprowadziła do powstania kolejnej delimitacji Krakowskiego Obszaru Funkcjonalnego, zrealizowanej na potrzeby narzędzia Zintegrowanych Inwestycji Terytorialnych (ZIT). Instrument ten ma na celu wspieranie partnerstw miast oraz jednostek wchodzących w skład ich obszarów funkcjonalnych, których przeznaczeniem będzie realizacja wspólnych przedsięwzięć finansowanych Regionalnego Programu Operacyjnego Województwa Małopolskiego w ramach nowej perspektywy finansowej 2014-2020. 


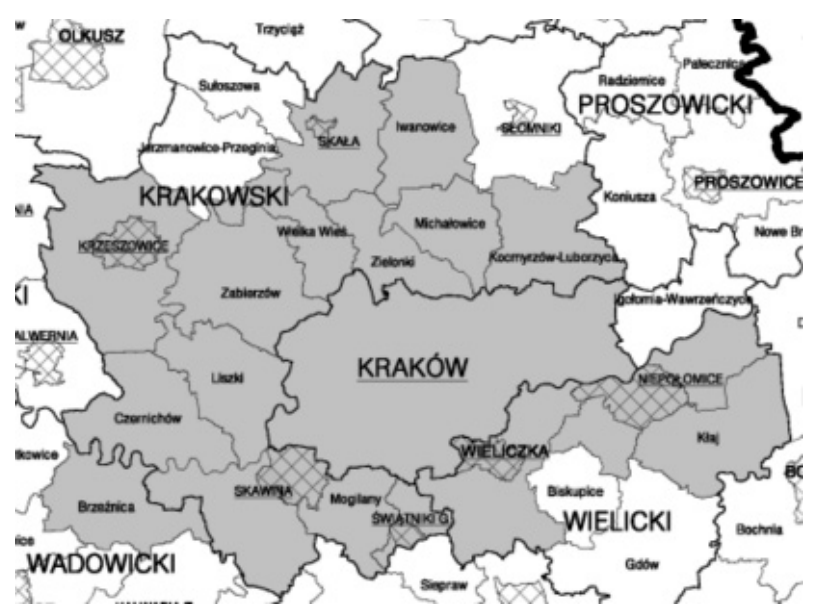

Rysunek 3. Delimitacja Krakowskiego Obszaru Metropolitalnego zawarta w Małopolskim Regionalnym Programie Operacyjnym na lata 2007-2013

Źródło: Uszczegółowienie Małopolskiego Regionalnego Programu Operacyjnego na lata 2007-2013, Zarząd Województwa Małopolskiego, Kraków 2008, s. 104.

Wyznaczony na podstawie Kryteriów delimitacji Obszarów Funkcjonalnych ośrodków wojewódzkich obszar funkcjonalny Krakowa jest jednocześnie przykładem najwęższej delimitacji zasięgu jego funkcji metropolitalnych (rysunek 4). Składa się na niego zaledwie 14 gmin (6 miejsko-wiejskich i 8 wiejskich), których łączna powierzchnia wynosi $1276 \mathrm{~km}^{2}$ [BDL, GUS, 2013]. Terytorium to zamieszkuje 1034142 mieszkańców. Delimitacja Krakowskiego Obszaru Funkcjonalnego w znacznym stopniu odbiega od zaleceń ustanowionych przez Ministerstwo Rozwoju Regionalnego. Pozytywnym aspektem tych odstępstw jest jednakże włączenie gminy Igołomia-Wawrzeńczyce do obszaru funkcjonalnego Krakowa. Jednostka ta była konsekwentnie pomijana w delimitacjach KOM następujących po wyznaczeniu tego obszaru w Planie Zagospodarowania Przestrzennego Województwa Małopolskiego.

Chociaż brak zgody co do delimitacji Krakowskiego Obszaru Metropolitalnego, to nie ulega wątpliwości, że granice funkcjonalne Krakowa (jako ośrodka centralnego) rozszerzają się coraz bardziej i wykraczają poza powszechnie obowiązujący podział administracyjny jednostek samorządu terytorialnego. Oznacza to, że prawidłowe zarządzanie rozwojem KOM wymagać będzie od wszystkich interesariuszy JST - zarówno od instytucji władzy samorządowej, jak i partnerów społecznych oraz całych zbiorowości wchodzących w jego skład - współpracy w tworzeniu i wdrażaniu polityk publicznych. Podejście partnerskie jest bowiem podstawą nowego paradygmatu zarządzania rozwojem terytorialnym. 


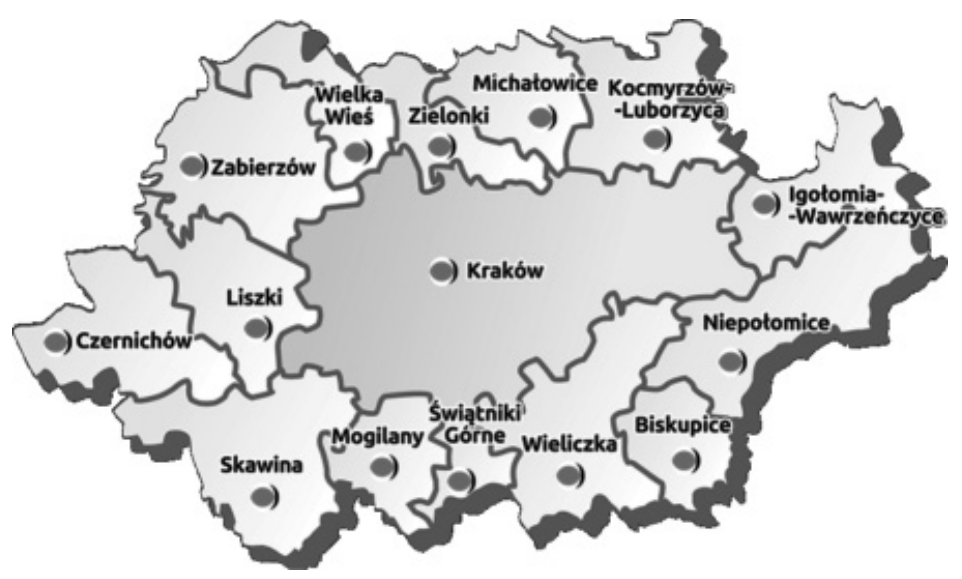

Rysunek 4. Delimitacja Krakowskiego Obszaru Metropolitalnego zawarta w projekcie Strategii Zintegrowanych Inwestycji Terytorialnych dla Krakowskiego Obszaru Funkcjonalnego Źródło: oficjalna strona internetowa Stowarzyszenia Metropolia Krakowska: http://metropoliakrakowska.pl/ [dostęp: 25.02.2015].

\section{Zakończenie}

Podsumowując prowadzone rozważania, należy zaznaczyć, że w warunkach Krakowa, niezależnie od przyjętej delimitacji, zarządzanie terytorialne oznacza konieczność nawiązania trwałej współpracy pomiędzy gminami o niezwykle zróżnicowanym potencjale - od jednostek samorządu terytorialnego poddanych procesom silnej suburbanizacji, stanowiących „bazę noclegową” dla osób pracujących w ośrodku centralnym, po jednostki o dużym znaczeniu turystycznym, kulturowym i historycznym (np. Wieliczka, Bochnia) oraz gospodarczym (np. Niepołomice, Skawina). Niezbędne wydaje się więc znalezienie wspólnych dla przedstawicieli tak zróżnicowanych zbiorowości wzorców i norm kulturowych, dzięki którym możliwe będzie sprawne wprowadzanie polityk publicznych i wykorzystanie potencjałów tych JST. Ich brak będzie bowiem powodował wzajemną nieufność oraz wrogie nastawienie samorządów wobec Krakowa, jako ośrodka centralnego, którego zasoby i wpływy traktowane będą jako niechciane i zagrażające dalszemu funkcjonowaniu znajdujących się w jego otoczeniu gmin.

Dlatego też niezbędne wydaje się rozpoczęcie współpracy w zakresie ustalania aktualnie obowiązujących norm kulturowych oraz wypracowywania metod i kierunków zmian relacji pomiędzy ośrodkiem centralnym a samorządami wchodzącymi w skład obszaru funkcjonalnego metropolii Kraków. Postulat ten wydaje się o tyle ważny, że już teraz - pomimo niewątpliwego „rozlewania się” funkcjonalnych granic Krakowa - brak konsensusu odnośnie do zasięgu procesów metropolizacji, a tym samym delimitacji obszaru funkcjonalnego i rozpoczęcie realnej (tzn. nieopartej wyłącznie na korzyściach finansowych związanych z dystrybucją 
środków zewnętrznych w ramach RPO WM) współpracy JST. Kształtowanie odpowiedniej kultury organizacyjnej pozwoli na skuteczne zarządzanie terytorialne Metropolią Kraków.

Ze względu na fakt, że tożsamość metropolitalna jest traktowana jako zmienna wewnętrzna organizacji, powinna być postrzegana przede wszystkim jako rezultat zarówno oddolnych działań społeczności lokalnych, jak i prowadzenia przez władze publiczne długofalowych i skrupulatnie wypracowanych polityk publicznych. Obejmować musi zasady współżycia społecznego, w tym kanały komunikacji, jednocześnie pozostawiając miejsce dla rozwoju kreatywności i samorealizacji jednostek. Dlatego też wykształcenie tożsamości metropolitalnej należy traktować jako proces długofalowy, wymagający partnerskiej współpracy władz samorządowych, organizacji pozarządowych, przedsiębiorców, a także mieszkańców i grup nieformalnych.

Tożsamość metropolitalna może tym samym stanowić odpowiedź na, wymuszane przez procesy globalizacji oraz metropolizacji, zmiany dotyczące sposobu funkcjonowania i zarządzania jednostkami samorządu terytorialnego. Aktywne zaangażowanie w kształtowanie nowej formy identyfikacji, podzielanej przez mieszkańców całej metropolii, stanowi kluczowy element zapewniający trwałą współpracę wszystkich społeczności lokalnych.

\section{Bibliografia}

Albert S., Whetten D.A., (2004), Organizational Identity [w:] M.J. Hatch, M. Schultz (red.), Organisational Identity. A Reader, Oxford University Press, Oxford - New York.

Bank Danych Lokalnych, Główny Urząd Statystyczny (stan na 26.04.2015).

Bassand M. (2007), Metropoles et Metropolisation [w:] Enjeux de la sociologie urbanie, Presses Polytechniques et Universitaires Romandes, Lausanne.

Derudder B., Taylor P.J., Ni P., De Vos A., Hoyler M., Hansens H., Basens D., Huang J., Witlox F., Shen W., Yang X. (2010), Pathways of Change: Shifting Connectivities in the World City Network, „Urban Studies”, 47, s. 1861-1877.

Dobrowolski Z. (2014), Zarzadzanie $w$ jednostkach samorzadu terytorialnego $w$ warunkach społecznej partycypacji $w$ realizacji zadań publicznych, „Zeszyty Naukowe Wyższej Szkoły Oficerskiej Wojsk Lądowych”, nr 1(171), s. 180-191.

Hausner J. (2010), W kierunku rządzenia interaktywnego [w:] A. Bosacki, H. Izdebski, A. Nelicki, I. Zachariasz (red.), Nowe zarzadzanie publiczne $i$ public governance $w$ Polsce $i$ w Europie, Liber Sp. z o.o. Warszawa.

Huculak M., Dej M., Jarczewski W. (2013), Powiązania infrastrukturalne i funkcjonalne gmin wiejskich w ramach obszaru metropolitalnego - przypadek Krakowskiego Obszaru Metropolitalnego, „Studia Obszarów Wiejskich”, t. XXXIV, s. 131-148.

Jałowiecki B. (2000), Społeczna przestrzeń metropolii, Wydawnictwo Naukowe Scholar, Warszawa.

Jałowiecki B. (2005), Polskie miasta w procesie metropolizacji, „Studia Regionalne i Lokalne", nr 1(19), s. 5-15. 
Klasik A., Biniecki J., Ochojski A. (2014), Metropolitalny foresight strategiczny: metodologia i studium przypadku, Komitet Przestrzennego Zagospodarowania Kraju PAN, Warszawa.

Kowalewski A. (2005), Przez metropolie do dobrobytu?, „Studia Regionalne i Lokalne”, nr 1 (19), s. 15-35.

Killman R.H., Covin T.Y. (2008), Corporate Transformation Revitalizing Organisation for a Competetive World, Josey-Bass Publishing, San Francisco, CA.

Kryteria delimitacji Miejskich Obszarów Funkcjonalnych ośrodków wojewódzkich, (2013), Ministerstwo Rozwoju Regionalnego, Warszawa.

Markowski T., Marszał T. (2006), Metropolie, obszary metropolitalne, metropolizacja. Problemy $i$ pojęcia podstawowe, Komitet Przestrzennego Zagospodarowania Kraju PAN, Warszawa.

Markowski T. (2007), Funkcje metropolitalne pięciu stolic województw wschodnich,

https://www.mir.gov.pl/rozwoj_regionalny/poziom_regionalny/strategia_rozwoju_polski_ wschodniej_do_2020/dokumenty/Documents/17d0ccd2c3f14ed3893369e56d59849cMar kowski.pdf [dostęp: 25.01.2015].

Markowski T. (2008), Teoretyczne podstawy rozwoju regionalnego i lokalnego [w:] Strzelecki Z. (red.), Gospodarka regionalna i lokalna, Wydawnictwo Naukowe PWN, Warszawa, s. 13-25.

Noworól A. (2007), Planowanie rozwoju terytorialnego w skali regionalnej i lokalnej, Wydawnictwo Uniwersytetu Jagiellońskiego, Kraków.

Noworól A. (2013), Ku nowemu paradygmatowi planowania terytorialnego, CeDeWu, Warszawa.

Parysek J.J. (2000), Polskie metropolie jako ogniwa procesu transformacji i przemian przestrzenno-strukturalnych (na tle metropolii europejskich) [w:] Z. Mikołajewicz (red.), Uwarunkowania i strategie rozwoju regionalnego w procesach integracji europejskiej, Wydawnictwo Uniwersytetu Opolskiego, Opole, s. 361-380.

Raporty na temat wielkich miast Polski. Kraków (2011), PwC.

Raźniak P. (2012), Procesy społeczno-ekonomiczne w Krakowskim Obszarze Metropolitalnym, „Prace Geograficzne”, Instytut Geografii i Gospodarki Przestrzennej UJ, nr 129, s. $63-81$.

Schein E. H., (1985), Organisational Culture and Leadership. A Dynamic View, Jossey-Bass Publishing, San Francisco, CA.

Schein E.H. (2004), Organisational Culture and Leadership, John Wiley \& Sons, San Francisco, CA.

Smętkowski M., Jałowiecki B., Gorzelak G. (2009), Obszary metropolitalne w Polsce: Problemy rozwojowe i delimitacja, „Raporty i Analizy EUROREG”, nr 1 (35), s. 52-73.

Sułkowski Ł. (2008), Czy warto zajmować się kultura organizacyjną?, „Zarządzanie Zasobami Ludzkimi”, nr 6, s. 9-25.

Śleszyński P. (2013), Delimitacja Miejskich Obszarów Funkcjonalnych stolic województw, „Przegląd Geograficzny”, nr 85(2), s. 173-197.

Uchwała nr XV/174/03 Sejmiku Województwa Małopolskiego z dnia 22 grudnia 2003 r. w sprawie uchwalenia Planu Zagospodarowania Przestrzennego Województwa Małopolskiego.

Uszczegółowienie Małopolskiego Regionalnego Programu Operacyjnego na lata 2007-2013, Uchwała nr 204/08, Zarządu Województwa Małopolskiego z dnia 13 marca 2008 r. 